\title{
Projective techniques in consumer research
}

\section{Suné Donoghue}

\section{OPSOMMING}

Projektiewe tegnieke behels ' $n$ dubbelsinnige stimulus waarvolgens die subjek sy/haar persoonlikheid, houdings, opinies en selfkonsep - as integrale deel van die self - in ' $n$ situasie projekteer ten einde struktuur of betekenis daaraan te gee. Projektiewe tegnieke word in kwalitatiewe verbruikersgedrag- en bemarkingstudies gebruik om subjekte se onbewuste of "verskuilde" gevoelens, houdings en motiewe bloot te lê en om stereotipiese en sydige responspatrone uit te skakel.

Projektiewe tegnieke word in kwalitatiewe verbruikersgedragnavorsing gebruik en aan die hand van die ontwerp en struktuur, verskillende tipes en die analise en interpretasie van data ontgin deur die gebruik van projektiewe tegnieke beskryf. Geldigheids- en betroubaarheidsoorwegings asook die nadele en voordele van projektiewe tegnieke word bespreek. Gevallestudies word beskryf om te toon hoe projektiewe tegnieke met ander kwalitatiewe data-insamelingsmetodes (diepteonderhoude en fokusgroeponderhoude) gekombineer kan word om meer insig oor die hoe, waarom en wat van verbruikers se gedrag te bekom.

\section{- Ms S Donoghue}

Department of Consumer Science, University of Pretoria

\section{INTRODUCTION}

Various projective techniques for personality assessment and psychoanalytic treatment in clinical psychology have increasingly gained acceptance since World War II (Bellak, 1992; Graham \& Lilly, 1984:212; Kassarjian, 1974:3-85). A set of projective techniques that were originally developed by clinical psychologists was adapted for use in consumer and marketing research (Berkman \& Gilson, 1986:365; Loudon \& Della Bitta, 1993:619; Kassarjian, 1974:3-85). These techniques became generally known as motivation research.

Projective techniques are not exclusively used to study consumer motivation, nor do these techniques contain all the tools for such studies. Motivation research shares many techniques with other consumer research areas using qualitative rather than quantitative research approaches (Loudon \& Della Bitta, 1993:619).

Projective techniques may be classified as a structured-indirect way of investigating the whys of situations (Webb, 1992:125). They are not used to measure (that is more the territory of other techniques such as surveys), but to uncover feelings, beliefs, attitudes and motivation which many consumers find difficult to articulate (Webb, 1992:125-126). Projective techniques help the researcher enter the private worlds of subjects to uncover their inner perspectives in a way they feel comfortable with (Gordon \& Langmaid, 1988:90; Loudon \& Della Bitta, 1993:619).

This article describes the use of projective techniques in qualitative consumer research. Psychology's basic theoretical foundations - from which the use of projective techniques in consumer research evolved - are briefly discussed. Projective techniques are described with reference to their design and structure, the different types of projective technique are discussed, as are the analysis and interpretation of data generated by using projective techniques. Their reliability and validity are investigated, and the advantages and disadvantages of projective techniques are discussed. Case studies are presented where projective techniques have been used outside the clinical setting.

\section{THEORETICAL FOUNDATIONS OF PROJECTIVE TECHNIQUES IN PSYCHOLOGY}

Projective techniques involve the use of vague, ambiguous, unstructured stimulus objects or situations in which the subject "projects" his or her personality, attitude, opinions and self-concept to give the situation some structure (Adams \& Schvaneveldt in Burns \& 
Lennon, 1993; Webb, 1992:113). Projective techniques uncover the innermost thoughts and feelings of a person, those aspects that are particular to this person, in other words the essence of his or her individuality (Kline, 1983:35). Projective techniques are also used to discover the person's characteristic modes of perceiving his or her world and how to behave in it (Chaplin in Sampson, 1986:41).

In psychoanalytic literature the concept "projection" is viewed as a defence mechanism with which the ego protects itself from anxiety by externalising unpleasant feelings or experiential elements - often directly ascribing them to others (Gordon \& Langmaid, 1988:95; Kline, 1983:35).

Projective techniques are based on the underlying principle that unconscious desires and feelings can be inferred by presenting a subject with an ambiguous situation in which he or she has to use the ego defence mechanism of projection. The subject is free to interpret and respond to the ambiguous stimuli (material that can be variously interpreted) from his or her own particular frame of reference (Churchill, 1991:322; Kassarjian, 1974:3-86; Loudon \& Della Bitta, 1993:300; Solomon, 1994:25). As there are no right or wrong answers, it is hoped that the subjects will project their own unconscious feelings in their answers (Solomon, 1994:25).

Examples of commonly used projective techniques for personality and clinical assessment include the Rorschach Inkblot Test, the Thematic Apperception Test (TAT), drawing techniques and sentence completion techniques (Janda, 1988:281-301; Piotrowski et al, 1993; Crumbaugh, 1990:5).

\section{PROJECTIVE TECHNIQUES IN CONSUMER RE- SEARCH}

\section{Projective techniques - a way of transcending communication barriers}

In certain circumstances it is impossible to obtain accurate information about what people think and feel by asking them to communicate their thoughts and feelings with direct questioning (Haire, 1950). In the typical interview, the subjects do not always share their innermost feelings with the researcher - who is after all a stranger. Moreover, the subjects are frequently unaware of their underlying motives, aspirations, values and attitudes in buying a product or choosing one brand instead of another (Berkman \& Gilson, 1986:365; Haire, 1950). They may fear being considered irrational or "stupid" and may therefore be reluctant to admit to certain types of (purchasing) behaviour. They consequently shade their responses to the interviewer.

Some social conventions or barriers may constrain the expression of feelings and reporting of behaviours. Subjects tend to offer answers that are socially acceptable and stereotypical in an interview situation
(Green, 1984). Many individuals avoid saying exactly what they think because they are, by nature, polite and tend to behave politely towards the interviewer (Berkman \& Gilson, 1986:365; Oppenheim in Sampson, 1986:42-43; Will et al, 1996).

Instead of questioning them directly, the subjects may be asked to respond indirectly, either talking about other people, these other people's feelings, attitudes and opinions, or about objects or situations. In talking about a third party or an object, the subjects project their covert feelings to the third party or object, and once these are in the open they may be discussed (Webb, 1992:125; Sampson, 1986:41; Dillon et al, 1987:136).

A subject's responses to projective techniques are not taken at face value, in other words meaning what the subject expects them to mean, but are interpreted in terms of underlying meanings of manifest behaviour (Levy, 1981; Sampson, 1986:42). It therefore becomes possible to circumvent people's "defensive" reactions (Berkman \& Gilson, 1986:365).

\section{Design and structure of projective techniques}

The stimuli range from structured (clear and definite) at one extreme, to very ambiguous (unstructured) at the other extreme. It is assumed that the more unstructured and ambiguous a stimulus, the more the subjects will project their emotions, motives, attitudes and values. The structure of a stimulus determines the degree of choice available to the subject. A highly structured stimulus, for example a questionnaire that requires the subjects to read a list of statements and answer "true" or "false" to each, leaves very little choice. The subject has an unambiguous choice among clear alternatives and the stimuli will probably be interpreted similarly by almost everyone who reads them (Levy in Churchill, 1991:322, 324; Graham \& Lilly, 1984:208). Ambiguous stimuli (with little structure), for example Rorschach inkblots, present a wide range of alternative choices and the subjects may choose their own interpretations. Semi-ambiguous pictures and sentence completion techniques represent an intermediate position on the stimulus continuum (Wagner, 1995; Graham \& Lilly, 1984:208).

In consumer and marketing research applications, projective techniques should constitute relatively ambiguous stimuli to permit the subjects to interpret the stimuli in terms of their own perceptions and in their own words. The nature of the stimuli should however offer enough direction to evoke some association with the concept of interest (Churchill, 1991:322-324; Gordon \& Langmaid, 1988:95; Thorndike in Berkman \& Gilson, 1986:368).

The stimuli can seldom be used directly as presented in the psychology literature. In consumer and marketing research, the stimuli are changed or modified to direct the respondents to discuss their deepest feelings and attitudes to a particular research problem (Gordon \& Langmaid, 1988:95). The TAT is perhaps 
the most flexible projective technique in marketing and consumer research as the TAT pictures may be modified to fit most marketing and consumer research problems, ranging from image studies to underlying consumer attitudes (Kassarjian, 1974:3-92; Churchill, 1991:324; Berkman \& Gilson, 1986:367).

The Rorschach inkblot test has not been used much, nor has it been adapted for use in marketing research (Kassarjian, 1974:3-93; Gordon \& Langmaid, 1988:96). It is assumed that the Rorschach test reveals deep layers of the unconscious - the forces that give rise to psychoses. It would therefore be folly to assume that these same forces underlie aspects of consumer behaviour (Kassarjian, 1974:3-94).

\section{Types of projective techniques}

Projective techniques have been categorised in terms of the response types required of subjects. The first category is association. The subjects are presented with a stimulus and they respond by indicating the first word, image or thought elicited by the stimulus (Burns \& Lennon, 1993).

In the case of word association, the subjects are asked to read a list of words and to indicate the first word that comes to mind. The answers provide the researcher with a variety of "consumer vocabulary" associated with brands or products (Green, 1984). This can be useful in discovering a brand image or product attributes. Brand personification requires the subjects to associate a brand or product with a person or personality type. With the pictures and words technique, the subjects are given a number of words and pictures and are asked to choose those they associate with a brand or product and to explain their choice. This allows the researcher to discover the more emotional responses to brands and imagery (Green, 1984; Gordon \& Langmaid, 1988:95-98).

In the second category, namely construction, the subject is asked to construct a story or a picture from a stimulus concept (Burns \& Lennon, 1993). The construction procedure requires more complex and controlled intellectual activity on the part of the subject. The subjects are for example handed a picture or a series of pictures in which consumers and products are the primary topics. One or more persons are usually depicted in ambiguous situations and the subjects are asked to describe or assume the role of one of these people. They have to tell what this person is thinking, saying and doing. The subjects are asked to build a story around each picture, what led to it and what may happen in future (Dillon et al, 1987:136; Churchill, 1991:324; Gordon \& Langmaid, 1988:101103). These pictures derive from the psychologist's TAT.

Projective questioning (third person techniques) requires the subjects to give opinions of other people's actions, feelings or attitudes. "Bubble" drawings or cartoon tests provide an opportunity to fill in the thought or speech bubbles of the characters depicted in ambiguous situations that are of interest to the researcher (Gordon \& Langmaid, 1988:101-106).

A third projective technique is completion. The subject is given an incomplete sentence, story, argument or conversation, and asked to finish it (Burns \& Lennon, 1993). Sentence completion is useful when time is limited, but depth of feeling still has to be tapped (Green, 1984; Gordon \& Langmaid, 1988:99).

According to Gordon and Langmaid (1988:101), brand mapping is a completion technique for which a variety of competing brands are displayed. The subjects are asked to group these brands according to some subject-stipulated characteristic. Brand mapping may be used in new product development and as a way to gain an understanding of how subjects view a product market.

A fourth projective technique is termed "expressive". A subject is asked to role-play, act, draw or paint a specific concept or situation (Burns \& Lennon, 1993). Expressive techniques focus on the manner in which the subject constructs something, rather than on what it represents (Gordon \& Langmaid, 1988:106).

Choice ordering is a last type of projective technique and it is frequently used in quantitative research. However, the technique is informally used in qualitative research when the subjects have to explain why certain things are "most important" or "least important", or to "rank" or "order" or "categorise" certain factors associated with a product, brand or service (Gordon \& Langmaid, 1988:112-113; Burns \& Lennon, 1993).

\section{Analysis and interpretation of data}

Interpreting data generated by using projective techniques follows two broad approaches. In quantitative analysis, the content of verbal or pictorial descriptions or sorted information is analysed by classifying the content into categories that are then given numerical values (Burns \& Lennon, 1993). Specific components of the test protocol are thus tabulated and used systematically to evaluate either a subject's responses or the empirical validity of generalisations about groups (Levy, 1981).

Qualitative analysis accepts introspection as data and looks for subjective meanings, thus acknowledging the need for interpretation (Levy, 1981). Qualitative analysis and interpretation of projective techniques are no different from the procedures for qualitative research in general. There are no systems of scoring or tabulation. Instead the description and explanation of the projections by the subjects form the database which then requires ordering and interpretation (Gordon \& Langmaid, 1988:118). It is phenomenological and interested in symbolic interactionism, trying to see what lies behind or is meant by manifest behaviour (Levy, 1981). Consumer researchers use a range of interpretive approaches to data, including semiotic analysis (Alexander et al in Catterall \& lbbotson, 2000) and

Projective techniques in Consumer Research 
story grammars (Mick et al in Catterall \& Ibbotson, 2000).

\section{Reliability and validity}

The value of any instrument, whether it is a selfadministered questionnaire or a projective technique, is dependent on the validity and reliability of the collected data (Kassarjian, 1974:3-95).

Dozens of studies in the psychology literature point to adequate reliability and validity of the carefully developed and standardised projective techniques that are often used by psychologists. On the other hand an equal number of studies suggest that these techniques are not sufficiently reliable or valid (Kassarjian, 1974:3-95). One may well ask whether the projective techniques modified by marketing and consumer researchers provide reliable and valid data (Kassarjian, 1974:3-95).

Reliability refers to the stability with which a technique yields information (Macfarlane \& Tuddenham, 1951:35). In temporal reliability projective techniques must for example yield data that are stable over time. If subjects are tested and later retested, their responses must remain similar and highly correlated (Kassarjian, 1974:3-95). Obviously, a subject's basic need-value system (his or her underlying motivations) are enduring. If the responses are affected by situational factors, the technique is unreliable and the data are generally unusable (Kassarjian, 1974:3-95).

Another form of reliability that is crucially important to any projective technique is coder or interpreter reliability. If two equally competent interpreters interpret the data in a significantly different manner, the technique should be questioned (Macfarlane \& Tuddenham, 1951:36).

Reliability may be established through triangulation, that is the use of two or more methods of data collection (Cohen \& Manion in Burns \& Lennon, 1993; Belk et al in Burns \& Lennon, 1993). Combining projective techniques with informal interviewing will enhance their value. Projective stimuli are often used in conjunction with individual interviews, and focus-group moderators also use projective stimuli to enhance focus-group discussions (Gordon \& Langmaid, 1988:114; Solomon, 1994:25).

Validity refers to the degree in which the technique measures what it is supposed to measure. If the projective technique purports to measure underlying motivation (need-value system), how well does it actually measure this basic substructure of the individual? (Kassarjian, 1974:3-96).

The purpose of projective techniques is to get below the surface of the underlying need-value system of the individual, his or her personality and motivations (Kassarjian, 1974:3-97). This implies that the researcher must be skilled to categorise and interpret response protocols. Allocating information to catego- ries requires logical argumentation and interpretation of data. A skilled and experienced researcher contributes to the inferential validity of a study, in other words the validity of the logical inferences drawn during execution of a research project.

Whereas the clinician is concerned with internal validity, that is whether a study has generated accurate and valid findings about the individual who has been studied, the marketing and consumer researcher is concerned with external validity, that is whether the findings of a project can be generalised in similar cases (Kassarjian, 1974:3-96). Kassarjian (1974:396) questions the external validity of projective techniques when the marketing or consumer researcher has to generalise from a small and perhaps unrepresentative sample to a population of potential users or buyers. Webb (1992:128) believes that projective techniques are useful in the exploratory stage of a research project, when ideas and hypotheses are required. When projective techniques have brought hidden attitudes or feelings into the open, other research techniques may be employed - techniques that are capable of rendering results that can be used to generalise about the characteristics of a population, for example survey methods and attitude scales (Webb, 1992:129).

\section{Advantages and disadvantages of projective tech- niques}

The primary disadvantage of projective techniques is the complexity of the data and the corresponding skills required of the researcher (Burns \& Lennon, 1993). The responses have little meaning without careful evaluation by researchers who are both trained and skilled interpreters of information. For this reason projective techniques are heavily criticised. A considerable degree of subjectivity applies in the interpretation of responses to projective techniques, and the experts frequently disagree among themselves (Sampson, 1986:42; Churchill, 1991:325).

Projective techniques are expensive to administer because highly skilled research staff have to be employed. Moreover, it is difficult to perform projective tests with statistically significant samples, and this restricts generalisation of the results to the population as a whole (Webb, 1992:129).

It may be difficult to get the subjects to project themselves into the roles the researchers wish them to assume. Some subjects may not agree to participate in exercises such as role playing (Webb, 1992:128; Berkman \& Gilson, 1986:368).

The reliability of measures is very difficult to establish. However, triangulation does establish reliability (Belk et al in Burns \& Lennon, 1993).

Employing projective techniques does have several advantages, for example the amount, richness and accuracy of the information that is collected (Burns \& Lennon, 1993; Wagner, 1995). Projective techniques 
can make a significant contribution if the research is concerned with beliefs, values, motivation, personality or other aspects related to individuals, their unique cognitions and behaviour (Kassarjian, 1974:3-97; Webb, 1992:128). These techniques provide a view of the overall functioning of individuals (Thorndike in Berkman \& Gilson, 1986:368).

A variety of projective techniques is frequently used in the context of intensive individual interviews or conventional focus-group discussions (Sampson, 1986:40; Webb, 1992:125; Solomon, 1994:25). These techniques may be introduced at different stages in the discussion once the subjects feel comfortable with the moderator and each other (Green, 1984). Projective techniques may be used as a way of "breaking the ice" in a focus-group discussion at the start of a qualitative research project (Webb, 1992:128). Subjects enjoy projective techniques that create new energy in a group discussion and lighten the mood or tone of the proceedings (Gordon \& Langmaid, 1988:89; Green, 1984).

The nature of appraisals is usually well disguised and the subjects are not aware of the purpose of the exercise. Even if they are aware of the general nature of the appraisal, they do not know which aspects of their responses are significant or the extent of this significance. The tasks presented to the subjects are usually somewhat novel and quite unstructured. They do not perceive right or wrong answers to the exercise and are encouraged to respond with a wide range of ideas (Burns \& Lennon, 1993; Wagner, 1995; Thorndike in Berkman \& Gilson, 1986:368).

Projective techniques supplement and verify intuition in generating hypotheses - hypotheses on why consumers behave as they do, why they buy or not and why they are influenced or not may emerge from the response protocols. These hypotheses should subsequently be tested and verified by way of experimental techniques, panel studies and surveys among representative samples according to carefully designed procedures (Kassarjian, 1974:3-97, 3-98).

Most of these techniques make little or no demand in terms of literacy or academic skills. They are predominantly nonreading, largely independent of particular languages, and in some cases do not involve speech at all. Their scope is therefore much wider than that of self-reporting or rating procedures (Thorndike in Berkman \& Gilson, 1986:368).

\section{Case studies}

Three case studies are discussed below to illustrate the use of projective techniques as a research tool.

Will et al (1996) demonstrated that projective techniques are extremely useful in opening discussions or debating issues that are socially sensitive, or where subjects may be embarrassed, lack knowledge or fear self-incrimination.
The research aimed at exploring the respondents' perceptions of factors that affect their health; awareness and knowledge of contraceptives and wellwoman services; their attitudes, feelings and experience of these services; barriers to use, and knowledge, attitudes and behaviour in connection with contraception.

The research was conducted by using a qualitative focus-group methodology and projective techniques that were developed specifically for the project. A word association technique was used to encourage the subjects to think about factors that affect their health. The factors were written on cards and presented one at a time to the subjects for discussion. Using an association technique with prompt cards allowed the moderator to use a choice-ordering technique asking the subjects to rank the factors, for example which were important for health and which were least important? Sentence completion and projective questioning techniques involved asking the subjects how someone else might complete a sentence or to comment on "other people's" experiences. The subjects reacted favourably to these sentences or "quotes" and began to discuss their own experiences openly.

Another technique these researchers used was an adaptation of an element of brand mapping. The subjects were encouraged to examine and discuss a range of contraceptives that were displayed on a tray. This allowed the research team to gather interesting insights into the subjects' awareness and perceptions of different contraceptives. This information would otherwise have been difficult to generate through a more direct questioning approach without the use of visual aids to facilitate discussion (Will et al, 1996).

Will et al (1996) stated that the application of projective techniques is not restricted to social cause issues and that these techniques would also be of value to those in commercial marketing and consumer research who seek to understand how a product might overcome certain social barriers to entry.

Donoghue (1998) followed a qualitative research strategy, using unstructured interviews and projective techniques to explore and describe the role of social motives and consumer stereotyping in selected upcoming consumers' choice of large electrical household appliances.

The projective techniques that were used included sentence completion and construction. The construction techniques involved asking the subjects to respond to pictures that depicted ambiguous situations relevant to the aspects that were being studied. The subjects were asked to assume the role of and to characterise the person depicted in each picture. They had to describe what was going on in each picture, what gave rise to it and what they expected the outcome to be. 
The results of this study indicated among other things that social motives seemed to guide the subjects' choice of large electrical household appliances. These subjects apparently formed stereotypes of their reference groups and allocated certain symbolic meanings to them, based on their ownership of large electrical household equipment.

Donoghue (1998) successfully demonstrated that projective techniques may be used to reveal consumers' hidden attitudes, feelings, beliefs and motives that are intimately associated with the decision to buy or not to buy.

Catterall and Ibbotson (2000) employed projective techniques in an education research project. They had to contribute to the evaluation of a computerbased guide to a university library. The students were invited to use the guide and the researchers subsequently administered a range of projective techniques.

The projective techniques they used were word association, sentence completion, cartoon bubble completion, picture sorting and product personification. The product personification technique required the students to imagine that the guide was a person and to complete, on this person's behalf, a dating agency application form. Three distinctive "persons" emerged from the responses and the students helped to interpret them.

When the students were asked to personify the guide, some thought of it as an electronic librarian (dull and boring). Others thought of it as a rather superior librarian (a well-informed person who lets you know the right way to go). Still others personified the library guide in terms of the technology or platform (expensive and glossy, good to look at but not much underneath it all, or, nice form but not much substance).

Although Catterall and Ibbotson (2000) experienced a few design pitfalls, they demonstrated that projective techniques could be fun and engaging for the subjects, especially when they become involved in the analysis and interpretation.

\section{CONCLUSION}

Gordon and Langmaid (1993:3) believe that qualitative research may be used optimally in situations that would increase understanding, expand knowledge, clarify the real issues, generate hypotheses, identify a range of behaviours, explain and explore consumer motivations, attitudes and behaviour, identify distinct behavioural groups, and provide input for future research. Qualitative research is mainly used for answering "how", "why" and "what" questions. It is not used for "how many" questions, that is the provenance of the quantitative research schools of thought (Webb, 1993:112).
In consumer research qualitative data collection methods include group discussions, individual in-depth interviews, observation and projective techniques (Webb, 1992:112). Group discussions and individual in-depth interviews have both advantages and disadvantages. Whereas direct questions elicit responses that may be simple to verbalise, projective techniques reveal subjective thoughts and emotions. Projective techniques may be used in combination with individual interviews and group discussions to overcome some of the problems associated with both. Projective techniques therefore complement other qualitative data collection methods by drawing complete portraits of consumers.

Kidder in Webb (1992:125) says projective techniques are useful in ...encouraging in subjects a state of freedom and spontaneity of expression where there is reason to believe that subjects cannot easily evaluate or describe their motivations or feelings ... or where topics on which subjects may hesitate to express their opinions directly for fear of disapproval by the investigator or when subjects are likely to consider direct questions as unwarranted invasion of privacy or to find them threatening for some other reason.

It is possible to use projective techniques to find out from a consumer what the phenomenological characteristics of various products may be, in other words the value character of a product in the consumer's life and not the physical characteristics of the product (Haire, 1950). Projective techniques are fundamental to consumer research in that they provide a greater depth of understanding of what people truly think and feel about a product (Green, 1984; Will et al, 1996).

\section{REFERENCES}

BERKMAN, HW \& GILSON, C. 1986. Consumer behaviour. Concepts and strategies. 3rd ed. Boston. Kent.

BELLAK, L. 1992. Projective techniques in the computer age. Journal of Personality Assessment 58(3):445-453.

BURNS, LD \& LENNON, SJ. 1993. Social perception: methods for measuring our perception of others. International Textile and Apparel Association Special Publication 5:153159.

CATTERALL, M \& IBBOTSON, P. 2000. Using projective techniques in education research. British Educational Research Journal 26(2):245-247.

CHURCHILL, GA. 1991. Marketing research methodological foundations. 5th ed. Chicago. Dryden.

CRUMBAUGH, JC. 1990. The meaning of projective techniques. In Crumbaugh, JC, Graca, J, Hutzell, RR, Whiddon, MF \& Cooper, EC. 1990. A primer of projective techniques of psychological assessment. California. Libra.

DONOGHUE, S. 1998. 'n Verkennend-beskrywende ondersoek na die rol van sosiale motiewe en verbruikerstereotipering by bepaalde swart, vroulike, opkomende verbruikers se keuse van groot elektriese huishoudelike toerusting. Skripsie vir Magistergraad in Huishoudkunde. Pretoria. Universiteit van Pretoria.

DILLON, WR, MADDEN, TJ \& FIRTLE, NH. 1987. Marketing research in a marketing environment. St Louise. Times Mirror. GORDON, W \& LANGMAID, R. 1988. Qualitative market research. Aldershot. Gower.

GRAHAM, JR \& LILLY, RS. 1984. Psychological testing. Engle- 
wood Cliffs, NJ. Prentice-Hall.

GREEN, J. 1984. Approaching the core of consumer behaviour. Marketing Research November:19-20.

HAIRE, M. 1950. Projective techniques in marketing research. Journal of Marketing Research 14(5):649-656.

JANDA, LH. 1998. Psychological testing: theory and applications. Boston. Allyn \& Bacon.

KASSARJIAN, HH. 1974. Projective methods. In Ferber, R. 1974. Handbook of marketing research. New York. McGrawHill.

KLINE, P. 1983. Personality: measurement and theory. London. Hutchinson.

LEVY, SJ. 1981. Interpreting consumer mythology: a structural approach to consumer behaviour. Journal of Marketing 45:4961.

LOUDON, DL \& DELLA BITTA, AJ. 1993. Consumer behaviour: concepts and application. 4th ed. New York. McGraw-Hill.

MACFARLANE, JW \& TUDDENHAM, RR. 1951. Problems in the validation of projective techniques. In Anderson, $\mathrm{HH} \&$
Anderson, GL. 1951. An introduction to projective techniques. Englewood Cliffs, NJ. Prentice-Hall.

PIOTROWSKI, C, KELLER, JW \& OGWA, T. 1993. Projective techniques: an international perspective. Psychological Reports 72:179-182.

SAMPSON, P. 1986. Qualitative research and motivation research. In Worcester, RM \& Downham, J. 1986. Consumer market research handbook. 3rd ed. Amsterdam. Elsevier.

SOLOMON, MR. 1994. Consumer behaviour. Buying, having and being. 2nd ed. Boston. Allyn \& Bacon.

WAGNER, EE. 1995. A logical analysis of projective techniques based on independence of items and latitude of response. Perceptual and Motor Skills 81:868-870.

WEBB, JR. 1992. Understanding and designing marketing research. London. Academic Press.

WILL, V, EADIE, D \& MACASKILL, S. 1996. Projective and enabling techniques explored. Marketing Intelligence and Planning 14(6):38-44. (Special Issue: Qualitative Market Research.) 